\title{
Combination therapy of zinc and trimethoprim inhibits infection of influenza $A$ virus in chick embryo
}

\author{
Magdi H. El Habbal* (1)
}

\begin{abstract}
Background: Respiratory RNA viruses including influenza virus have been a cause of health and economic hardships. These viruses depend on its host for replication and infection. Influenza virus infection is lethal to the chick embryo. We examined whether a combination of trimethoprim and zinc (Tri-Z), that acts on the host, can reduce the lethal effect of influenza A virus in chick embryo model.

Method: Influenza virus was isolated from patients and propagated in eggs. We determined viral load that infects $50 \%$ of eggs ( $50 \%$ egg lethal dose, ELD ${ }_{50}$ ). We introduced $10 \mathrm{ELD}_{50}$ into embryonated eggs and repeated the experiments using $100 \mathrm{ELD}_{50}$. A mixture of zinc oxide (Zn) and trimethoprim (TMP) (weight/weight ratios ranged from 0.01 to $0.3, \mathrm{Zn} / \mathrm{TMP}$ with increment of 0.1 ) was tested for embryo survival of the infection ( $n=12$ per ratio, in triplicates). Embryo survival was determined by candling eggs daily for 7 days. Controls of Zn, TMP, saline or convalescent serum were conducted in parallel. The effect of Tri-Z on virus binding to its cell surface receptor was evaluated in a hemagglutination inhibition (HAl) assay using chicken red cells. Tri-Z was prepared to concentration of $10 \mathrm{mg}$ TMP and $1.8 \mathrm{mg}$ Zn per $\mathrm{ml}$, then serial dilutions were made. HAl effect was expressed as scores where $++++=$ no effect; $0=$ complete HAl effect.
\end{abstract}

Results: TMP, Zn or saline separately had no effect on embryo survival, none of the embryos survived influenza virus infection. All embryos treated with convalescent serum survived. Tri-Z, at ratio range of 0.15-0.2 (optimal ratio of 0.18 ) $\mathrm{Zn} / \mathrm{TMP}$, enabled embryos to survive influenza virus despite increasing viral load ( $>80 \%$ survival at optimal ratio). At concentration of $15 \mu \mathrm{g} / \mathrm{ml}$ of optimal ratio, Tri-Z had total HAl effect (scored 0). However, at clinical concentration of $5 \mu \mathrm{g} / \mathrm{ml}$, Tri-Z had partial HAl effect $(++)$.

Conclusion: Acting on host cells, Tri-Z at optimal ratio can reduce the lethal effect of influenza A virus in chick embryo. Tri-Z has HAl effect. These findings suggest that combination of trimethoprim and zinc at optimal ratio can be provided as treatment for influenza and possibly other respiratory RNA viruses infection in man.

Keywords: Chick embryo, Influenza virus, Trimethoprim, Zinc, Hemagglutination

\section{Introduction}

Respiratory RNA viruses are continuing to challenge man with epidemics and devastating pandemics. RNA and DNA synthesis require polymerase enzymes. While DNA

${ }^{*}$ Correspondence: elhabbel@elhabbel.karoo.co.uk

Mastropix Health Care, 35 Mew Walk, North Ferriby HU14 3AH, UK polymerases have read-proof abilities with correction facilities, RNA polymerases do not have such qualities whereby errors, i.e. mutations, occur [1]. Some of these mutations may allow RNA virus to cross species like SARS and COVID-19 whereby no vaccination existed. Mutations of influenza virus continue to cause yearly epidemics and, in 1918 and 2009, instigated pandemics [2]. 
Influenza virus can adapt to species specific haemagglutinin biding receptors on cell surface and then cross the species [3]. Crossing species is a threat to national and international public health with devastating health and socioeconomics burdens [4]. In the wrong hands, a technology involving respiratory RNA viruses may become a threat to national security. Public health education, vaccination and drug treatment are strategies whereby national security against threats of respiratory RNA virus pandemics is ensured.

In anticipation of the threats, we embarked on development on an anti-viral. We identified trimethoprim (TMP) and zinc ( $\mathrm{Zn}$ ) as potential candidates for treatment for RNA virus. RNA virus requires host cell wall receptors to infect and its nucleus to replicate [2]. TMP inhibits folate dehydrogenase where-by it affects nuclear DNA with deleterious effect on the cell and its wall [5]. In man, the effect is transient and mostly subclinical [6]. Zinc ions were demonstrated to inhibit RNA virus, rhinovirus [7]. When combined at a ratio TMP and Zn may treat respiratory RNA virus infections [8].

There are several respiratory RNA viruses including influenza virus, Coronavirus, Respiratory Syncytial virus and rhinovirus [9]. To infect, these viruses require attaching to the host cell surface receptors, internalization and replication using the host nucleus and intracellular organelles $[2,8,9]$. We used influenza virus as a model because it shares similar mechanisms for infection, replication and pathogenesis with that of the respiratory RNA viruses $[3,9]$.

Studies of influenza virus are usually carried out in ferret and/or mouse models. However, ferrets and mice are more susceptible to zinc toxicity than other species such as the chick embryo [10,11]. The chick requires zinc for normal development and can tolerate high intake of zinc supplied in appropriate diet $[12,13]$. Influenza virus infection is lethal to the chick embryo. Chick embryo is easy to access as a culture medium, highly susceptible to influenza virus, of low cost and was shown to be a reliable model for testing anti-influenza drugs $[14,15]$. In this study we examined the use of combination of TMP and $\mathrm{Zn}$ on chick embryo survival to influenza infection.

\section{Methods}

We isolated influenza virus from positive swabs from patients during influenza season and propagated it in white leg horn embryonate eggs. Virus detection was carried out using florescence immune assay (FIA) and its subtypes identified by using PCR (RT-PCR, TaqMan, Thermofisher Scientific) as previously described $[16,17]$.

\section{Virus isolation}

Virus was isolated from positive patient's swabs during influenza season. Virus strain identification was conducted as previously described [16-18]. We identified the strain H3N2 [A/England/215/2011 (H3N2) like-virus].

We used embryonated eggs as described by and according to $\mathrm{WHO}$ guidance for virus isolation and detection $[19,20]$. Briefly, eggs were incubated at $33-35^{\circ} \mathrm{C}$ and $70 \%$ humidity with air sac facing upward (to allow embryo development at the air sac position for ease of visualization). The choice of $33-35{ }^{\circ} \mathrm{C}$ is to allow optimal viral multiplications [21]. Eggs were candled daily to check for embryo growth. Before inoculation, the stage of development was determined by direct inspection through a window in the egg shell using Olympus dissecting microscope. Eggs that did not show live embryos at matching stage of development were removed and discarded. The stage of development was determined according to Hamburger and Hamilton [22]. Thus, embryos were tested at the same stage of development. On day 8 of incubation (Hamburger and Hamilton stage 34) eggs were used for virus isolation.

Influenza positive material $(0.2 \mathrm{ml})$ was mixed with broad spectrum antibiotic. The material was injected via the window using 22-gauge needle into amniotic and allantoic space. The window was sealed using bees wax. Eggs were candled daily to detect embryos survival. At day 11 of incubations, eggs were removed from incubator and placed in fridge at $4{ }^{\circ} \mathrm{C}$ for $1 \mathrm{~h}$ to reduce the likelihood of bleeding from allantoic membrane. The presence of the virus was determined by hem-agglutination (HA) test $[23,24]$.

We repeated the passage in chick embryos 3 times. From the last passage, allantoic fluids were collected to make a stock of the virus. The stock was tested for presence of the virus using standardized HA technique. Aliquots were made and stored in $-70{ }^{\circ} \mathrm{C}$ till used.

\section{Determination of $50 \%$ egg infective dose $\left(\mathrm{EID}_{50}\right)$}

It was made by inoculating $0.1 \mathrm{ml}$ of serial tenfold dilutions of virus. Eggs were incubated at $36{ }^{\circ} \mathrm{C}$ and candled daily to detect embryo survival. On day 8 on incubation, we injected $0.1 \mathrm{ml}$ of the virus into the allantoic cavity. The eggs were returned to the incubator for further $48 \mathrm{~h}$ at $36^{\circ} \mathrm{C}$. Eggs were opened to determine embryo survival or death. The allantoic fluid from each egg, was tested for the virus by HA test. We used 12 eggs per dilution and repeated the experiments 3 times. The dilution that caused $50 \%$ death of embryos (egg infectious doses, $\operatorname{EID}_{50}$ ) was determined using survival and death as described by Reed and Muench [25]. We calculated the dilution that contain $100 \mathrm{EID}_{50}$ according to the 
equation: Log dilution of virus suspension containing 100 $\mathrm{EID}_{50}=\log \mathrm{EID}_{50}+2$.

\section{Determining effect of Tri-Z}

Summary of the study protocol and groups are shown in Fig. 1 and Table 1, respectively.

The effect of Tri- $Z$ on influenza virus was tested using embryo survival as measure of effectiveness. For these experiments, we used eggs at day 6 of incubation (Hamburger and Hamilton stage 29) because it is a vulnerable (interferon deficient) period for the embryo [26]. The outcome of treatment is measured by percentage of survival (effective) or death (ineffective) of the embryos 7 days after inoculation.

Embryo survival was determined as heart is beating, and embryo is moving. Death of the embryo was recorded as being the breakdown of the visible blood vessel structures of the chorioallantoic membrane, the appearance of disseminated coagulation, blood leakage into the yolk or the allantoic fluid areas, the absence of heart beating, absence of movement of the embryo, and extensive autolysis [19].

All experiments were repeated three times to ensure reproducibility.

We made suspensions from mixture of TMP and $\mathrm{Zn}$ (Tri-Z). The $\mathrm{Zn} / \mathrm{TMP}$ ratio ranged from 0.01 to 0.3 with increment of 0.01 . TMP powder (Medex, UK) was suspended in sterile water at concentration of $10 \mathrm{mg} / \mathrm{ml}$. We added Zn oxide powder (Medex, UK) to generate the desired mixture ratio. We made fresh suspension/s prior to each experiment. It was shaken to allow for homogeneous distribution of the compounds. We tested 30 ratios with 12 eggs in each ratio group.

\section{Study groups}

On day 6 of egg incubation, the combined suspension was injected $(0.5 \mathrm{ml})$ into the air sac using plastic syringe through an 18-gauge needle. An hour later, $10 \mathrm{EID}_{50}$ was injected into the allantoic space as close as possible to the embryo (group 1). Eggs were returned to the incubator and candled daily for 7 days to determine embryo survival.

To evaluate the effect of increasing viral load, we repeated the same experiments but using $1_{100 \mathrm{EID}_{50}}$ virus suspension, (group 2).

\section{Controls}

To verify the effects of Tri- $Z$ on influenza virus, we carried out similar experiments in controls groups, at Hamilton and Hamburger stage 29 (day 6 of incubation). In each experiment, 12 fertilized eggs were used. We followed the study protocol but the test material varied based on the control group.

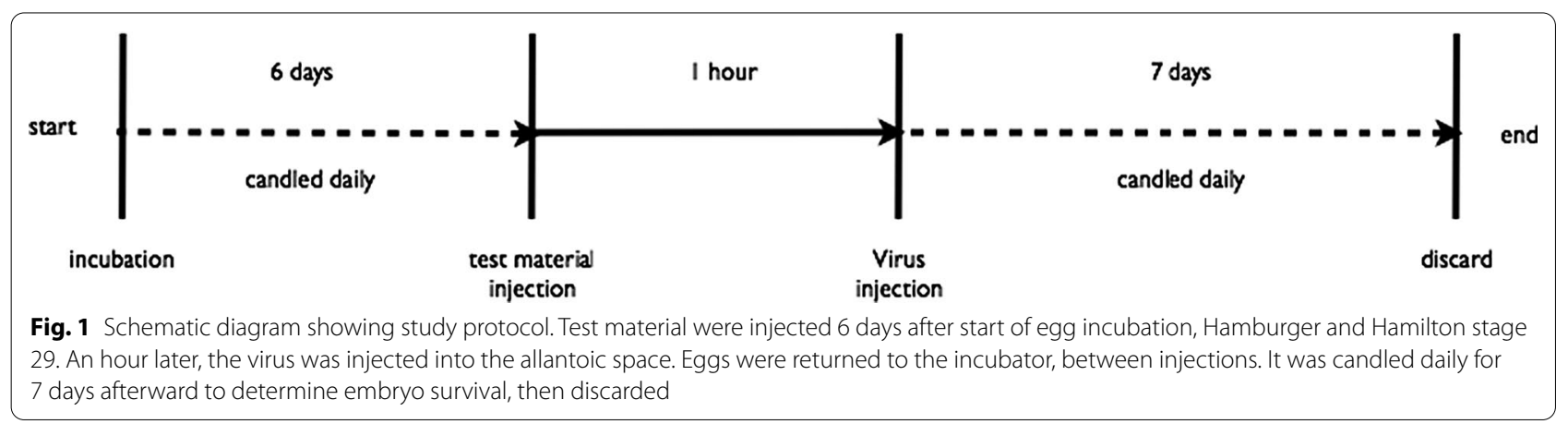

Table 1 It shows study groups

\begin{tabular}{llll}
\hline Group & Virus load & Treatment & Number of embryos \\
\hline group 1 & $10 \mathrm{EID}_{50}$ & Tri-Z: at Zn/TMP ratio 0.01 to 0.3 , increment of 0.01 (30 ratios) & 12 per ratio \\
group 2 & $100 \mathrm{EID}_{50}$ & Tri-Z: at Zn/TMP ratio 0.01 to 0.3 , increment of 0.01 (30 ratios) & 12 per ratio \\
C 1 & $10 \mathrm{EID}_{50}$ & $.5 \mathrm{ml} \mathrm{NS}$ & 12 \\
C 2 & $10 \mathrm{EID}_{50}$ & $\mathrm{Zn}: 0.05$ to $1.5 \mathrm{mg}$ with $0.05 \mathrm{mg}$ increments (30 concentrations) & 12 per concentration \\
C 3 & $10 \mathrm{EID}_{50}$ & $\mathrm{TMP}: 5 \mathrm{mg}$ & 12 \\
C 4 & $10 \mathrm{EID}_{50}$ & $0.2 \mathrm{ml}$ of convalescent serum & 12 \\
\hline
\end{tabular}

We carried experiments examining effect of a mixture of trimethoprim and zinc influenza virus. We examined two virus loads 10 EID $_{50}$ and 100 EID $_{50}$, in 6 day old chick embryos, group 1 and group 2. This was compared to control groups (C 1- C 4). Experiments were repeated in triplicates. EID $\mathrm{E}_{50}=$ egg infective dose 50 i.e. virus load that cause $50 \%$ mortality of the embryo, $C=$ control, $N S=$ normal saline, $T M P=$ trimethoprim, $Z n=z i n c$, Tri-Z: mixture of trimethoprim and zinc oxide 
First control (C1): The test material was an increasing dose of $\mathrm{Zn}$ (in $0.5 \mathrm{ml}$ saline, to match the amount of $\mathrm{Zn}$ in the respective ratio but without TMP) was injected into eggs in similar fashion.

Second control (C2): we used TMP only at a dose of $5 \mathrm{mg}$ in $0.5 \mathrm{ml}$ saline.

Third control (C3): we injected $0.5 \mathrm{ml}$ of normal saline into the eggs.

Fourth control (C4): To ensure that death of embryo occurred from viral infection, virus infected eggs (10 $\mathrm{EID}_{50}$ ) were incubated with and without neutralizing antibodies using periodate treated convalescent serum $(0.5 \mathrm{ml})$ from the patient as previously described [24].

\section{Hemagglutination (HA)}

As previously described [23, 24], hem-agglutinin titrations were carried out by adding $0.2 \mathrm{ml}$ of a $0.5 \%$ suspension of washed fowl erythrocytes (RBCs) to $0.2 \mathrm{ml}$ of each serial two-fold dilution of test material. The tests were read after $45 \mathrm{~min}$ at room temperature. The end point was the highest dilution showing compete HA which contains 1 HA unit (HAU)/0.05 ml.

\section{Hemagglutination inhibition (HAI)}

We carried out HAI as previously described [24] with Tri- $\mathrm{Z}$ as the test material. Tri- $\mathrm{Z}$ was prepared to concentration of $10 \mathrm{mg}$ TMP and $1.8 \mathrm{mg} \mathrm{Zn}$ per $\mathrm{ml}$, then serial dilutions were made. We added equal volumes of Tri-Z to that of $4 \mathrm{HAU}$ of virus. Then, fowl RBCs were added. The final mixture was incubated for $30 \mathrm{~min}$ at room temperature before reading [23]. To verify that the effect of Tri- $\mathrm{Z}$ is on the cell and not the virus, we repeated the same experiment except that the RBCs were incubated with Tri-Z for $30 \mathrm{~min}$, and then washed in PBS prior to addition to the virus. Results were expressed as previously described, where no $\mathrm{HA}=0$, some $\mathrm{HA}=+$, partial $\mathrm{HA}=++$, more than partial $\mathrm{HA}=+++$, complete $\mathrm{HA}=++++[23,24]$.

\section{Statistics}

We used the number of embryos surviving at day 7 after infection as a measure of the outcome of treatment. Data were tested for normality of distribution, and then parametric or non-parametric tests were applied accordingly. If data were normally distributed, we applied paired test to determine the significance of change in ratio on the survival of embryos. Where data were abnormally distributed, we applied Mann-Whitney test. To determine the significance of difference in survival with change in ratio we applied repeated analysis of variance. Chi square test was applied to identify the most significant ratio at which highest survival was achieved. Significance value was set at $\mathrm{p}<0.05[27,28]$.

\section{Results}

The virus isolated from patients was influenza virus H3N2 [A/England/215/2011(H3N2) like-virus infection].

At viral load of $10 \mathrm{EID}_{50}$, there was no embryo survival at ratios 0.01 to 0.04 and 0.26 to 0.3 . Embryo survival occurred at 0.05 to 0.25 ratios. At viral load of $100 \mathrm{EID}_{50}$, there was no embryo survival at ratios of 0.01 to 0.14 and 0.21 to 0.3 ; embryo survival occurred at ratio of 0.15 to 0.2 . The effect of changing $\mathrm{Zn}$ to TMP ratio on embryo survival is shown in Figs. 2 and 3. The effect of increasing viral load on embryo survival is shown in Fig. 4.

It appeared that with increasing the ratio of $\mathrm{Zn}$ to TMP embryo survival increased. It peaked at ratio about 0.18 ( $\mathrm{Zn} / \mathrm{TMP})$. There was decrease in the survival with further increase in the ratio. The data were normally distributed. The changes in $\mathrm{Zn}$ to TMP ratio had significant effect on the survival of the embryos, $p<0.001$. In cluster analysis, it seemed that there were three clusters, with one cluster showing much better survival than the other two clusters, $\mathrm{p}<0.001$. In that cluster, the range of effective ratio was 0.1 to 0.2 . The peak of surviving embryos was at ratio of 0.18, Fig. 2. With increasing viral load to $100 \mathrm{EID}_{50}$, the cluster distribution was abolished. Embryo survival was possible in $\mathrm{Zn} / \mathrm{TMP}$ ratio range $0.15-0.2$, with the peak survival at ratio of 0.18 , Fig. 3.

In C1, C2 and C3 groups, all embryos died. In C4, embryos survived which confirms that death of the embryos was a result of influenza virus infection.

The results from HAI studies whereby Tri-Z was mixed with the virus prior to addition $\mathrm{RBCs}$ and that where Tri-Z was incubated with RBCs prior to addition to the virus were the same. The highest dilution of the virus stock that caused HA was $1 / 4096$, thus containing 1 HAU. The dilution used that contained 4 HAU was $1 / 1048$. It was possible to achieve total HAI (score of 0 ) with Tri-Z at $15 \mu \mathrm{g} / \mathrm{ml}$. However, at $5 \mu \mathrm{g} / \mathrm{ml}$, HAI was partial scoring ++ comparing to controls of virus scoring ++++ and without virus scoring 0 . Neither Zn nor TMP separately had any observable HAI effect (scoring +++ ) similar to control virus, Table 2 and Fig. 5.

\section{Discussion}

This study shows that a combination of TMP and $\mathrm{Zn}$ (TriZ) can treat influenza virus infection in chick embryo independent of interferon. Six days old chick embryos treated with Tri- $Z$ survived the virus, comparing to controls. In 6 day old chick embryo, interferon is deficient [26] and the viral infection is lethal. Using TMP, zinc or normal saline separately did not enable embryo survival of the infection at $10 \mathrm{EID}_{50}$ or $100 \mathrm{EID}_{50}$. However, neutralizing antibodies in convalescent serum enabled 

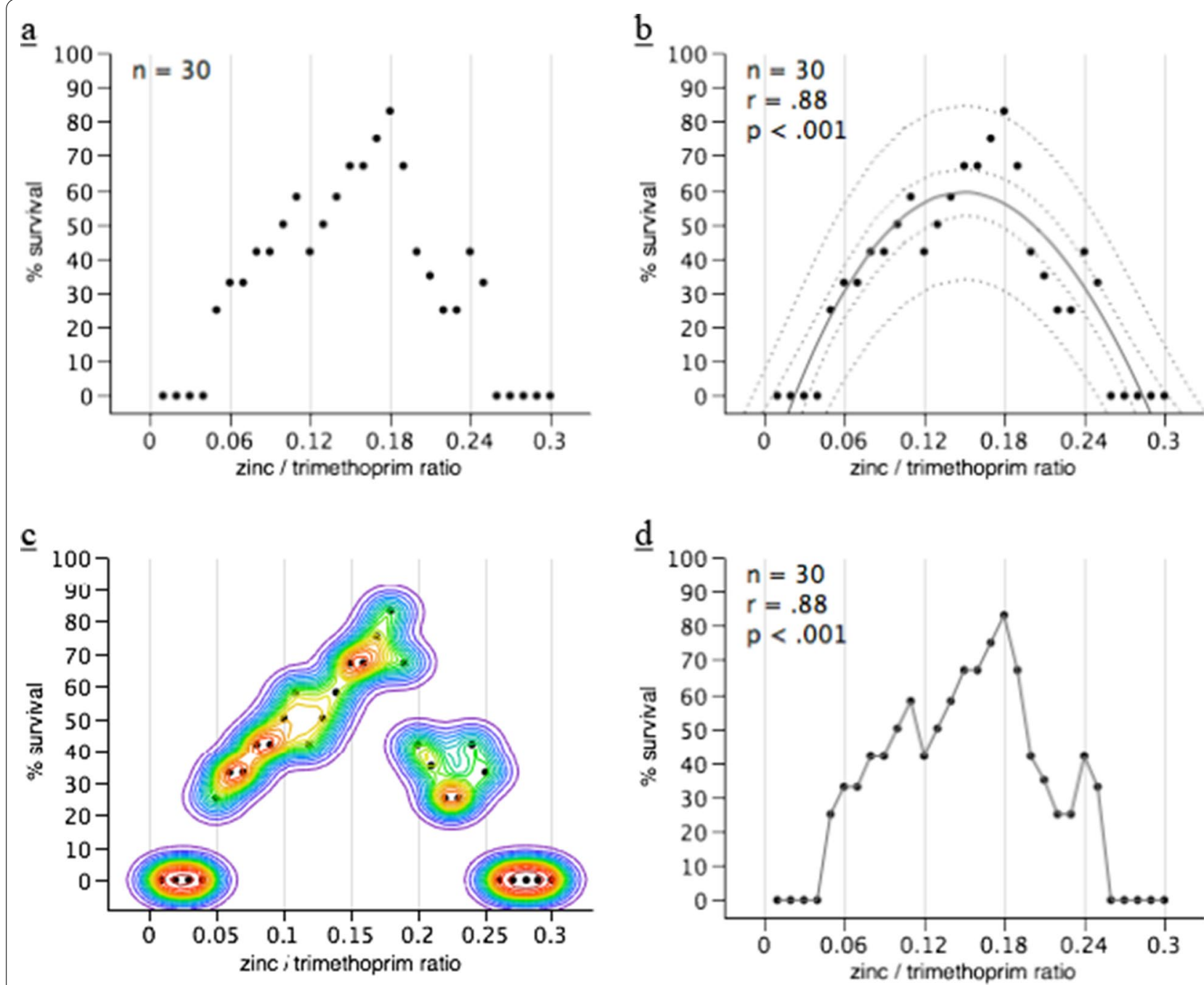

Fig. 2 To determine the ratio of $Z n$ to TMP that is most effective in treating viral influenza infection $\left(10 E_{1} D_{50}\right)$. Fertilised chicken eggs $(n=12)$ were infected with data shown with solid line connecting each data point. From (a) and (d) it seemed that the peak of survivors reached at Zn/TMP ratio of 0.18. However by analysing the data closely in (b) and (c) it appeared that the reliable Zn/TMP ratio is 0.15 . (a) Data are displayed as solid points. (b) Polynomial equation $\left(Y=65.603867-41.570169 \times X-3474.1479 \times(X-0.155)^{2}+1821.6868 \times(X-0.155)^{3}\right)$ was applied and mean (solid line) 1 and 2 standard deviations (dotted lines) were plotted. c Area analysis with colour variation whereby orange-red represent consistent data. $\mathbf{d}$ same plot as a with data points joined by solid lines

embryos to survive which confirmed that the cause of its death was infection by the virus.

Like other RNA viruses, influenza virus depends on its host cell and nuclear DNA for replication and spread [3], which is associated with an increase in amino acid synthesis [29]. Excluding host nuclear DNA by enucleation of cells prevents RNA virus replication $[30,31]$. Interfering with host DNA by TMP (which is a dihydro-folate reductase enzyme inhibitor) can disturb the hots processes for viral replication. While in bacteria, TMP affects DNA to a point that causes arrest of cell division (bacteriostasis) in man the effect is transient [6]. It was reported that TMP may have beneficial effect in treating DNA virus infections [32, 33]. However, for RNA virus, TMP on it is own is not effective. All embryos treated with TMP alone did not survive the infection, but with $\mathrm{Zn}$, the combination was effective.

Zinc was shown to inhibit replication of RNA virus, rhinovirus, in vitro [7]. In vivo, the effect was not quiet evident but thought to assist in ameliorating rhinovirus infections (common cold) [34]. In chick embryo, zinc did not inhibit influenza virus. All embryos treated 


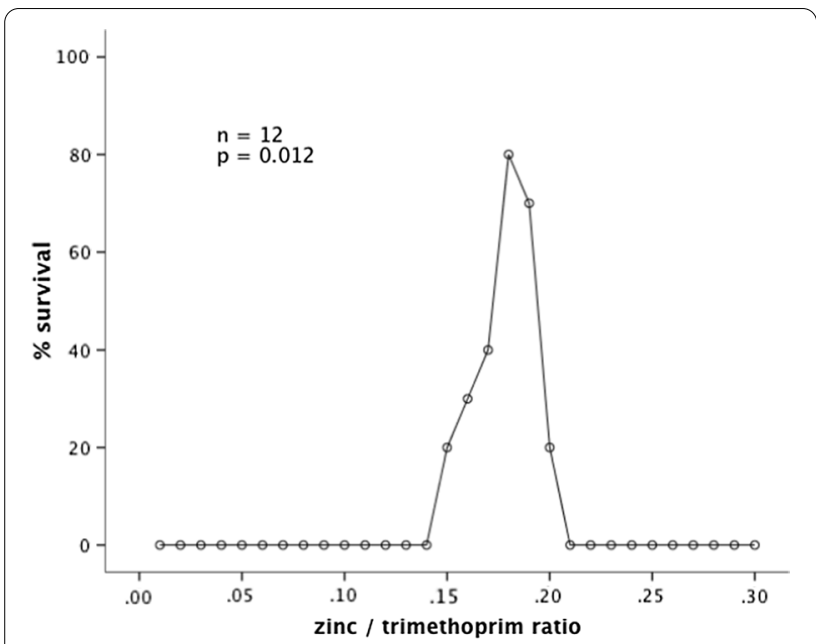

Fig. 3 It shows the effect of high viral load $\left(100 \mathrm{EID}_{50}\right)$ on chick embryo survival. We used the same ratios and doses as outlined in methods. Embryo survival was maximum at 0.18 ratio of $Z n$ to TMP

with $\mathrm{Zn}$ alone died from influenza virus infection. But, with TMP, the combination enabled embryo survival of influenza virus.
Zinc ions are key structural components of a large number of proteins. In eukaryotic cell under optimal conditions, $\mathrm{Zn}$ associates with protein forming $\mathrm{Zn}$ finger. A $\mathrm{Zn}$ finger is a small protein structural motif, characterized by the co-ordination of one or more zinc ions in order to stabilize the protein fold. Zn fingers bind RNA and mediate protein-protein interactions. A $\mathrm{Zn}$ finger protein was found to inhibit influenza virus replication [35-38]. Under experimental conditions, Zn combines with TMP forming fixed complex preserving the anti-bacterial properties of TMP but without evidence of anti-virus $[39,40]$. Whereas, in-vivo, the non-fixed formulation of $\mathrm{Zn}$ and TMP (Tri-Z) inhibited influenza virus in chick embryo, similar to that in man [8], enabling embryo survival of infection. The viral inhibition of Tri- $Z$ appears to be ratio dependent. We found that increasing ratio of $\mathrm{Zn}$ to TMP increased embryo survival, until an optimal ratio was reached, then embryo survival decreased with further increase in ratio. Increasing viral load from $10 \mathrm{EID}_{50}$ to $100 \mathrm{EID}_{50}$ reduced the range of the ratio that enables embryo survival. However, the optimal ratio remained unchanged. The ratio dependence indicates presence of an interaction between the two molecules when certain conditions are met. For example, in water, the $\mathrm{pH}$ of the
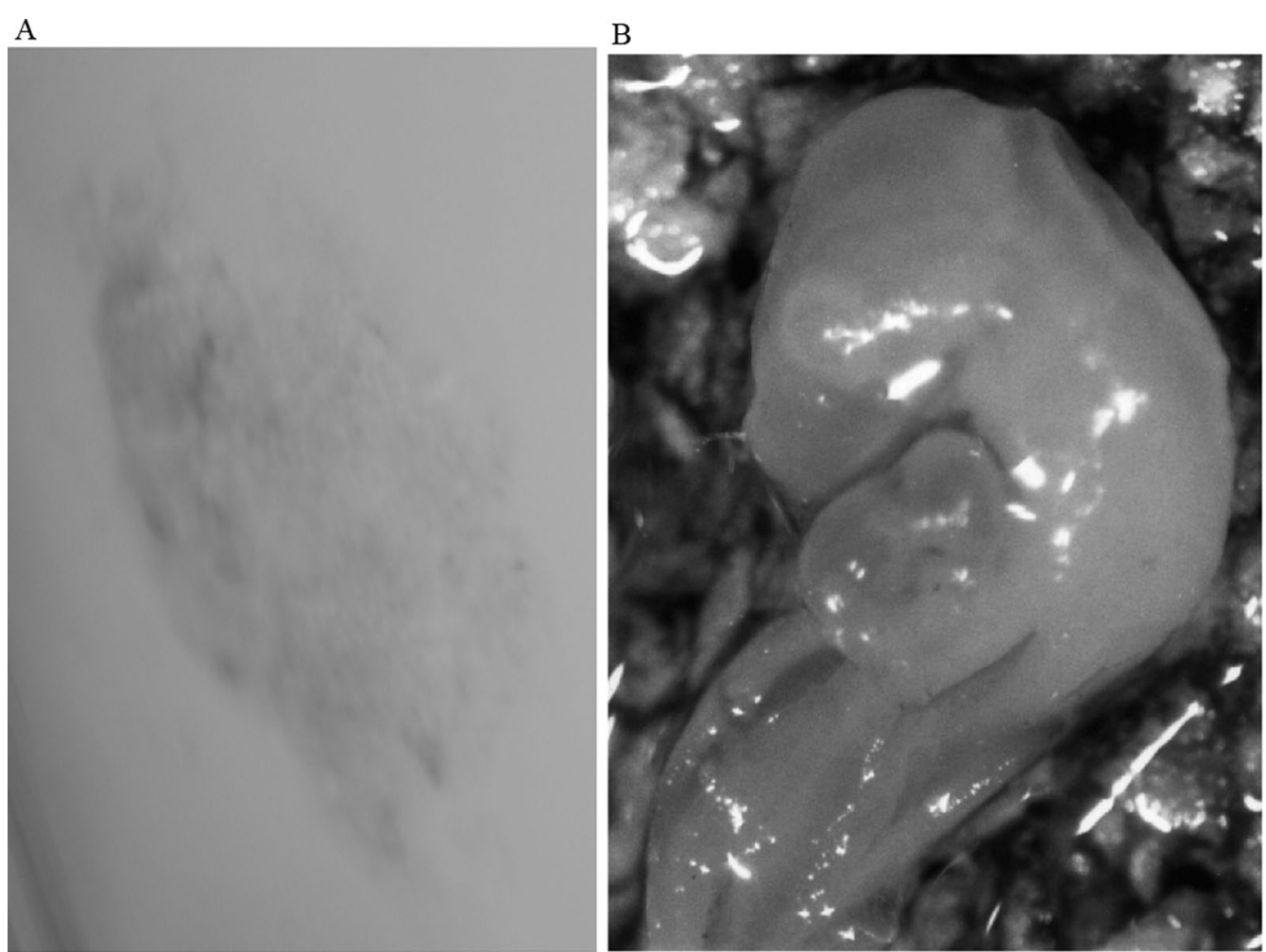

Fig. 4 The effect of virus infection at 6 days of incubation on check embryo survival. a shows complete disintegration of the embryo and failure to grow compared to that treated with Tri-Z (b) 
Table 2 It shows that Tri-Z, at ratio $5 \mathrm{mcq} / \mathrm{ml}$, had hemagglutination inhibition effect scoring ++comparing to TMP or Zn separately; - means no hem-agglutination, ++++ mean total hem-agglutination

\begin{tabular}{ll}
\hline Agent & Hemagglutination \\
\hline saline & - \\
virus & ++++ \\
serum and virus & - \\
Tri-Z and virus & ++ \\
TMP and virus & ++++ \\
Zn and virus & ++++ \\
\hline
\end{tabular}

Serum preparation from patients and hemagglutination were carried out as previously described $[23,24]$

combination at the optimal ratio of 0.18 is 7.24 which is the pKa of TMP. For TMP, $\mathrm{pH}=\mathrm{pKa}+\mathrm{Log} 10$ (protonated/unprotonated compound), as $\mathrm{pH}=\mathrm{pKa}$, then the ratio of protonated to unprotonated TMP is 1 . Such equilibrium in the charge of TMP is expected to allow association with $\mathrm{Zn}$ in a dynamic combination. Dynamic interactions between drugs were shown to occur at equilibrium and enhance its permeability across biological membrane to target RNA [41, 42]. This, perhaps, is similar to the $\mathrm{Zn}$ finger protein phenomenon.

Once introduced, the virus is not shed out of the egg. Inability of the virus to infect suggested that Tri- $Z$ prevented these infections from occurring. A possible mechanism of action is interfering with virus binding to its cell surface sialic acid-based receptor [43]. Virus binding to this receptor is a process by which HA occurs [23]. At ratio $0.18 \mathrm{Zn}$ to TMP, hemagglutination inhibition was possible. Previous studies showed a relationship between pharmacokinetics of TMP and sialic acid rich protein [44, 45]. Therefore, it seems that Tri-Z acts at multiple sites whereby the RNA virus utilizes the host to infect and replicate including the virus ability to bind to its cell surface receptor.

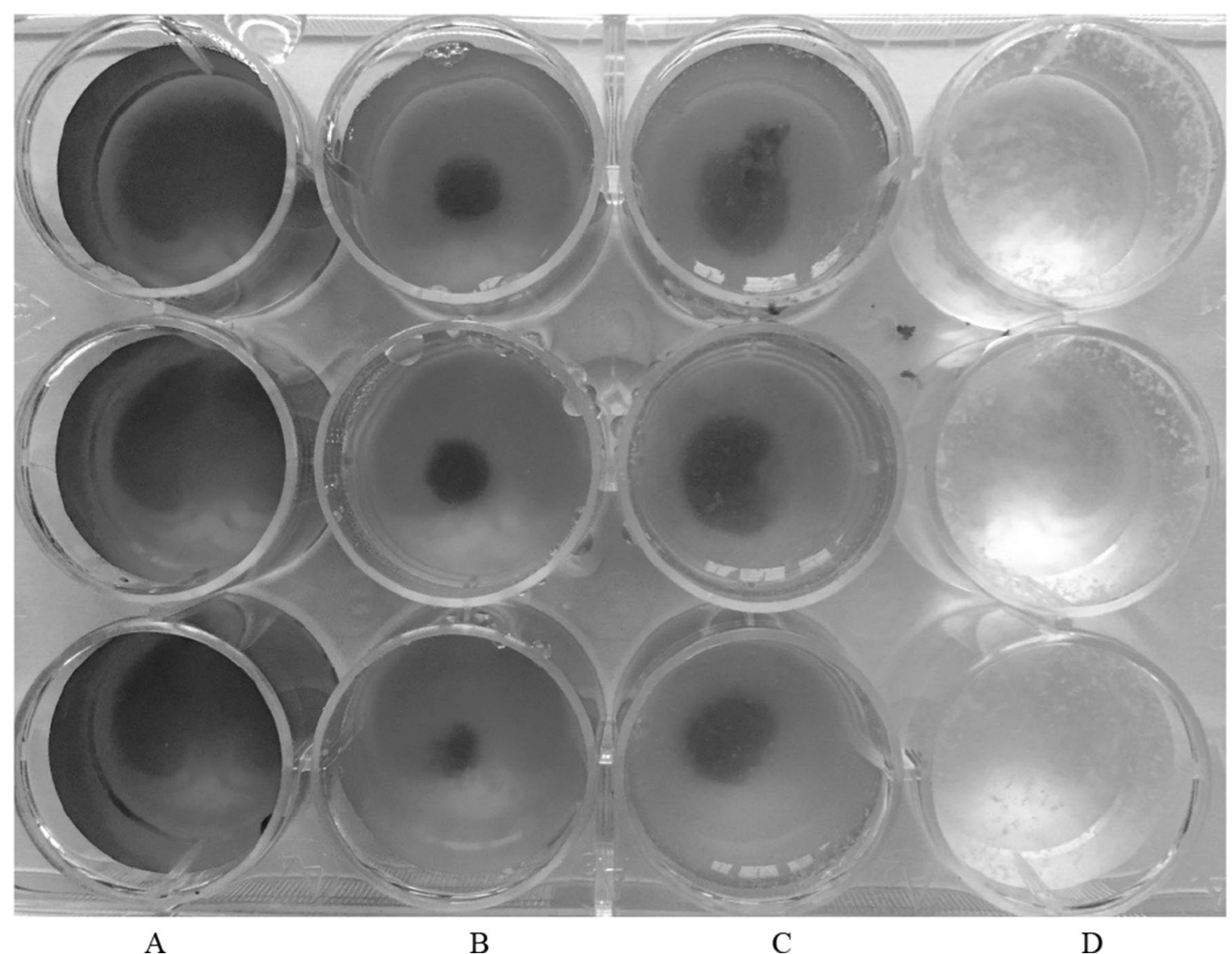

Fig. 5 It shows haemagglutination inhibition test using chicken red blood cells. In A, convalescent serum was added to neutralise the virus, there was no agglutination (-). In B, Tri-Z was added at $5 \mathrm{mcq} / \mathrm{ml}$, haemagglutination occurred but to less extent $(++)$ than that of no treatment in $C$ $(++++)$. In $D$, no red cells were added 
It may be thought that increasing use of TMP in this combination might increase bacterial resistance. TMP is a long-standing drug which is widely used and spread in the environment without emergence of new resistance [46].

\section{Conclusions}

We conclude that a combination of $\mathrm{Zn}$ and TMP enables chick embryo survival of influenza virus infection which is ratio dependent. At optimal ratio, the combination acts on host cells including cell surface receptor whereby it has haemagglutinin inhibition effect. Further studies to examine the use of Tri- $Z$ in treating patients infected with other respiratory RNA viruses are planned.

\begin{abstract}
Abbreviations
TMP:Trimethoprim; Tri-Z: Trimethoprim and zinc combination; Zn: Zinc; HA: Hemagglutination; HAl: Hemagglutination inhibition; HAU: Hemagglutination unit; ml: Milliliter; RBC: Red blood cells; EID: Egg infective dose; ${ }^{\circ} \mathrm{C}$ : Degree centigrade; WHO: World Health Organization; FIA: Florescence immune assay; RT-PCR: Reverse transcription polymerase chain reaction; RNA: Ribonucleic acid; DNA: Deoxyribonucleic acid; PBS: Phosphate buffered saline.
\end{abstract}

\section{Acknowledgements}

We thank Mr Damien Bove for his guidance and support in putting the studies together.

\section{Authors' contributions}

All authors contributed equally to the study and preparing the manuscript. All authors read and approved the final manuscript.

\section{Funding}

The studies were funded by Her Majesty's Revenue and Customs'research and development tax relief and credit system.

\section{Availability of data and materials}

All data are presented in the results section and expressed into graphic presentations. If any data, not already shared, are needed it may be made available.

\section{Declarations}

Ethics approval and consent to participate

All work described has been carried out in accordance with The Code of Ethics of the World Medical Association (Declaration of Helsinki) for experiments involving humans. All animal experiments are carried out in accordance with the U.K. Animals (Scientific Procedures) Act, 1986 and associated guidelines.

\section{Consent to publication}

No applicable.

\section{Competing interests}

The authors declare that they have no competing interests.

Received: 26 November 2020 Accepted: 27 May 2021

Published online: 03 June 2021

\section{References}

1. Drake JW, Holland JJ. Mutation rates among RNA viruses. Proc Natl Acad Sci U S A. 1999:96:13910-3.

2. Shaw ML, Palese P. Orthomyxoviridae. In: Knipe DM, Howley PM, editors. Field's virology. 6th ed. London: Lippincott Williams \& Will; 2013.
3. Bush RM. Influenza as a model system for studying the cross-species transfer and evolution of the SARS coronavirus. Philos Trans R Soc Lond B Biol Sci. 2004;359(1447):1067-73. https://doi.org/10.1098/rstb.2004.1481.

4. Riedel S. Crossing the species barrier: the threat of an avian influenza pandemic. Proc Bayl Univ Med Cent. 2006;19:16-20.

5. Nishino T, Wecke J, Krüger D, Giesbrecht P. Trimethoprim-induced structural alterations in Staphylococcus aureus and the recovery of bacteria in drug-free medium. J Antimicrob Chemother. 1987;19(2):147-59.

6. Sive J, Green R, Metz J. Effect of trimethoprim on folate-dependent DNA synthesis in human bone marrow. J Clin Pathol. 1972;25:194-7.

7. Korant BD, Kauer JC, Butterworth BE. Zn ions inhibit replication of rhinoviruses. Nature. 1974;248:588-90.

8. El Habbal MH. Zinc/Trimethoprim combination therapy. WO 2009/109531 (11.09.2009 Gazette 2009/37). https://patentimages.stora ge.googleapis.com/6f/ee/f3/555aad40853f57/EP2257292B1.pdf.

9. Hodinka RL. Respiratory RNA viruses. In: Hayden RT, Wolk DM, Carroll KC, Yi-Wei Tang Y, editors. Diagnostic microbiology of the immunocompromised host 2e. Washington, DC: American Society for Microbiology; 2016. https://doi.org/10.1128/microbiolspec.DMlH2-0028-2016.

10. Straube EF, Schuster NH, Sinclair AJ. Zinc toxicity in the ferret. J Comp Pathol. 1980;90:355-61.

11. Sun X, Lu L, Liao X, Zhang L, Lin X, Luo X, Ma Q. Effect of in ovo zinc injection on the embryonic development and epigenetics-related indices of zinc-deprived broiler breeder eggs. Biol Trace Elem Res. 2018;185:456-64.

12. Berg JM, Shi Y. The galvanization of biology: a growing appreciation for the roles of Zn. Science. 1996;271:1081-5.

13. Naz S, Idris M, Khalique MA, Zia-UR-Rahman, Alhidary IA, AbdeIRahman MM, Khan RU, Chand N, Farooq U, Ahmid S. The activity and use of zinc in poultry diets. World's Poult Sci J. 2016;72:159-67.

14. Watson BK, Coons AH. Studies of influenza virus infection in the chick embryo using fluorescent antibody. J Exp Med. 1954;99:419-28. https:// doi.org/10.1084/jem.99.5.419.

15. Wang JX, Zhou JY, Yang QW, Chen Y, Li X, Piao YA, Li HY. An improved embryonated chicken egg model for the evaluation of antiviral drugs against influenza A virus. JVirol Methods. 2008;153(2):218-22.

16. CDC protocol of realtime RTPCR for influenza A (H1N1). http://www.who. int/csr/resources/publications/swineflu/CDCRealtimeRTPCR_SwineH1Ass ay-2009_20090430.pdf.

17. WHO manual on animal influenza, diagnosis and surveillance. WHO/CDS/ CSR/NCS/2002.5 Rev. 1.

18. Lee MS, Chang PC, Shien JH, Cheng MC, Shieh HK. Identification and subtyping of avian influenza viruses by reverse transcription-PCR. J Virol Methods. 2001;97:13-22.

19. Sauerbrei A, Haertl A, Brandstaedt A, Schmidtke M, Wutzler P. Utilization of the embryonated egg for in vivo evaluation of the anti-influenza virus activity of neuraminidase inhibitors. Med Microbiol Immunol. 2006;195:65-71.

20. WHO. Recommended laboratory tests to identify avian influenza A virus in specimens from humans. 2005. https://biosafety.sinica.edu.tw/Recom mended\%20laboratory\%20tests\%20to\%20identify\%20avian\%20inf luenza\%20A\%20virus\%20in\%20specimens\%20from\%20humans.pdf.

21. Hirst GK. Direct isolation of human influenza virus in chick embryos. J Immunol. 1942:45:293-302

22. Hamburger $\mathrm{V}$, Hamilton HL. A series of normal stages in the development of the chick embryo. J Morphol. 1951;88:49-92.

23. Hirst GK. The quantitative determination of influenza virus and antibodies by means of red cells agglutination. J Exp Med. 1942;75:49-64.

24. Dowdle WA, Kendal AP, Nobel G. Influenza virus. In: Lennette EH, Schmidt $\mathrm{NJ}$, editors. Diagnostic procedures for viral, rickettsial and chlamydial infections. 5th ed. Washington: American Public Health Association Inc; 1979. p. 585-609.

25. Reed $\sqcup$, Muench $H$. A simple method of estimating fifty per cent endpoints. American J Epidemiol. 1938;27:493-7.

26. Morahan PS, Grossberg SE. Age-related cellular resistance of the chicken embryo to viral infections. I. Interferon and natural resistance to myxoviruses and vesicular stomatitis virus. J Infect Dis. 1970;121:615-23.

27. Bewick V, Cheek L, Ball J. Statistics review 12: survival analysis. Crit Care. 2004;8:389-94.

28. Bland M. An introduction to medical statistics. 2nd ed. Oxford: Oxford University Press; 1995 
29. Kalter SS. Amino acids present in allantoic fluid proteins from chick embryos infected with influenza virus. J Immunol. 1950;64:499-504

30. Follett EAC, Pringle CR, Wunner WH, Skehel JJ. Virus replication in enucleate cells: vesicular stomatitis virus and influenza virus. J Virol. 1974;13:394-9.

31. Kelly DC, Avery RJ, Dimmock NJ. Failure of an influenza virus to initiate infection in enucleate cells. JVirol. 1974;13:1155-I116.

32. Flore $O$, Marcialis NA, Firinu A, Bertolini A. Inhibitory action of 2,4 diamino 5 (3,4,5 trimethoxybenzyl) pyrimidine (TMP) on the growth of DNA viruses. Rivista di Farmacologiae Terapia. 1974;5:201-4.

33. Goldberge S, Sonji A, Marks NI. Inhibition of herpes virus replication by trimethoprim and co- trimethoxazole. Clin Res. 1976;24:676A.

34. Jackson JL, Lesho E, Peterson C. Zn and the common cold: a meta-analysis revisited. J Nutr. 2000;130:1512S-1515S.

35. Lin RJ, Huang CH, Liu PC, Lin IC, Huang YL, Chen AY, Chiu HP, Shih SR, Lin LH, Lien SP, Yen LC, Liao CL. Zinc finger protein ZFP36L1 inhibits influenza A virus through translational repression by targeting $\mathrm{HA}, \mathrm{M}$ and NS RNA transcripts. Nucleic Acids Res. 2020;48(13):7371-84.

36. Hui EKW, Smee DF, Wong MH, Nayak DP. Mutations in influenza virus $\mathrm{M} 1 \mathrm{CCHH}$, the putative $\mathrm{Zn}$ finger motif, cause attenuation in mice and protect mice against lethal influenza virus infection. J Virol. 2006;80:5697-707.

37. Judd AK, Sanchez A. D J Bucher, Huffman JH, Bailey K, and Sidwell RW: In vivo anti-influenza virus activity of a zinc finger peptide. Antimicrob Agents Chemother. 1997;41:687-92.

38. Wang W, Xiao H, Wu N, Shi H, Xu H, Zhou L, Xi XG, Wang T, Wang X. Characterization of the antiviral activity for influenza viruses M1 Zn finger peptides. Curr Microbiol. 2011;62:126-32.
39. Simó B, Perelló L, Ortiza R, Castiñeiras A, Latorre J, Canto E. Interactions of metal ions with a 2,4-diaminopyrimidine derivative (TMP) antibacterial studies. J Inorg Biochem. 2000;81:275-83.

40. Rehmani FS, Khan FA, Hassan F. Co-ordination of septran drug with trace metal ions in the biological system. Int J Biol Biotech. 2006;3:439-42.

41. Corbett PT, Leclaire J, Vial L, West KR, Wietor JL, Sanders JKM, Otto S. Dynamic combinatorial chemistry. Chem Rev. 2006;106:3652-711.

42. McAnany JD, Miller BL. Dynamic combinatorial chemistry as a rapid method for discovering sequence-selective RNA-binding compounds. Methods Enzymol. 2019;623:67-84.

43. Weis W, Brown JH, Cusack S, Paulson JC, Skehel JJ, Wiley DC. The structure of the influenza virus haemagglutinin complexed with its receptor, sialic acid. Nature. 1988;333:426-31.

44. Tagawa Y, Kokue E, Shimoda M, Son DS. a1-acid glycoprotein-binding as a factor in age-related changes in the pharmacokinetics of TMP in piglets. Vet Q. 1994;16:13-7.

45. Son DS, Shimoda M, Kokve E. Implication of altered levels of plasma alpha(1)-acid glycoprotein and its derived sialic acid on plasma protein binding of TMP in pigs in physiological and pathological states. Vet Q. 1996;18:10-3.

46. Straub JO. An environmental risk assessment for human-use TMP in European surface waters. Antibiotics. 2013;2:115-62.

\section{Publisher's Note}

Springer Nature remains neutral with regard to jurisdictional claims in published maps and institutional affiliations.
Ready to submit your research? Choose BMC and benefit from:

- fast, convenient online submission

- thorough peer review by experienced researchers in your field

- rapid publication on acceptance

- support for research data, including large and complex data types

- gold Open Access which fosters wider collaboration and increased citations

- maximum visibility for your research: over 100M website views per year

At BMC, research is always in progress.

Learn more biomedcentral.com/submissions 